УДК 344.13

DOI https:/ / doi.org/10.32837 / yuv.v0i2.1730

\title{
Н. Фєрьєва,
}

аспірантка кафедри кримінального права, кримінології, цивільного та господарського права

ВНЗ «Національна академія управління»

\section{ПОНЯТТЯ ТА СУСПІЛЬНА НЕБЕЗПЕЧНІСТЬ ЗЛОЧИНУ «ПОГРОЗА АБО НАСИЛЬСТВО ЩОДО НАЧАЛЬНИКА»}

Конституцією України у ст. 3 закріплено, що людина, ії життя і здоров'я, честь і гідність, недоторканність і безпека визнаються в Україні найвищою соціальною цінністю. Крім того, права, свободи та їх гарантії є під захистом держави. А у ст. 17 зазначено, що найважливішою функцією держави $€$ захист суверенітету й територіальної цілісності України. Оборона України, територіальна цілісність, захист суверенітету покладається на Збройні Сили України. I, відповідно, держава забезпечує соціальний захист громадян України, які перебувають на військовій службі. Кримінальний кодекс України 2001 р. загалом урахував ці положення Конституції України. Водночас дотримання військової дисципліни у Збройних Силах України та інших військових формуваннях, утворених відповідно до законів України, - це основа для виконання функцій захисту держави та громадян України. Командири й начальники, які віддають накази, мають бути впевнені в їх виконанні, а ст. 405 («Погроза або насильство щодо начальника») Кримінального кодексу України, котра передбачає кримінальну відповідальність за названі дії щодо начальника, має гарантувати їх недоторканність.

Висвітленню сутності кримінально-правової характеристики військового злочину, яка передбачає кримінальну відповідальність за погрозу або насильство щодо начальника, приділяли увагу у своїх працях такі укра- їнські науковці, як: Г.М. Анісімов, C.I. Дячук, M.I. Карпенко, B.I. Касинюк, M.I. Панов, M.I. Хавронюк, С.О. Харитонов, та інші вчені. Водночас питання суспільної небезпечності зазначеного військового злочину, передбаченого ст. 405 КК України, висвітлено недостатньо.

Метою статті є завдання звернути увагу наукової спільноти та громадськості на необхідності та важливості дослідження питань суспільної небезпечності військових злочинів, пов'язаних із посяганням на здоров'я, честь і гідність командирів і начальників, що $€$ одним із найнебезпечніших посягань на військову дисципліну як основу військового правопорядку.

Основою існування правової держави $€$ функціонування системи законів та норм права, які, зі свого боку, гарантують суспільну безпеку в державі за всіма напрямами іï діяльності виключно в інтересах людини. Зі свого боку, суспільна небезпечність виявляється у спричиненні або створенні небезпеки спричинення шкоди суспільним відносинам, зокрема, інтересам особи, суспільства, держави, які охороняються законом про кримінальну відповідальність. У кримінальних правопорушеннях проти встановленого порядку несення військової служби за ними стоять інтереси більш високого порядку воєнна безпека держави, а саме стан захищеності країни від озброєної агресії. Військові злочини підривають боєздатність військових підрозділів, а як 
наслідок - спричиняють шкоду військовому правопорядку. Тобто суспільна небезпечність злочинів проти військової служби виражається у спричиненні або у створенні загрози спричинення шкоди інтересам воєнної безпеки держави. Тому суспільна небезпечність військового злочину - погроза або насильство щодо начальника, передбаченого ст. 405 КК України, є очевидною, оскільки вчинення зазначеного злочину $€$ посяганням на командирів і начальників, які, відповідно до ст. 58 Статуту внутрішньої служби Збройних Сил України, затвердженого Законом України від 24.03.1999 р. № 548-XIV, $€$ єдиноначальниками у відповідних органах військового управління, військового командування, підрозділах й особисто відповідають перед державою за бойову та мобілізаційну підготовку довіреної їм військової частини, корабля, підрозділу; за забезпечення охорони державної таємниці; за бойову підготовку, виховання, військову дисципліну, морально-психологічний стан особового складу; за внутрішній порядок, стан i збереження озброєння, боєприпасів, бойової та іншої техніки, пального й матеріальних засобів; за всебічне забезпечення військової частини, корабля, підрозділу; за дотримання принципів соціальної справедливості. Тому успішне виконання ними своїх службових обов'язків $€$ необхідною умовою для забезпечення належної військової дисципліни й одночасно гарантує недоторканність як їх особи, так і їньої честі та гідності. Водночас судова статистика свідчить про протилежне. За період дії чинного КK України 2001 р. за вчинення злочину, передбаченого ст. $405 \mathrm{KK}$, було засуджено 212 військовослужбовців, із них після початку агресії Російської Федерації проти України, тобто із 2014 р., донині за цей злочин засуджено 138 військовослужбовців. У переважній більшості потерпілими були командири й начальники молодшої й середньої ланки, які пліч-о-пліч виконують свої обов'язки з особовим складом.
Недоторканність командира й начальника є тим маркером, котрий свідчить про стан військового правопорядку, під яким розуміється система суспільних відносин, що складається у збройних силах на основі норм загального й військового законодавства, статутів, наказів командирів і начальників, який визначається суспільно-політичним устроєм держави, призначенням його збройних сил і характеризується реальним використанням воїнами широких прав і свобод і виконанням обов'язків, передбачених Конституцією, військовим законодавством [1, с. 584].

Поняття «суспільна небезпечність діяння» (або «ступінь суспільної небезпечності діяння»), як зазначає О.О. Пащенко [2, с. 168], не може характеризувати соціальну обумовленість кримінально-правових норм інших видів (не охоронних) і тому не має універсального характеру.

B.B. Сташис, M.I. Бажанов та інші науковці вказували на ту обставину, що ознака суспільної небезпечності це підстава для криміналізації діяння [3]. I дійсно, етапом криміналізації дій у вигляді «погрози або насильства щодо начальника» стало прийняття 23 серпня 1922 р. Кримінального кодексу УСРР, уведеного в дію 15 вересня 1922 р., ст. 201 передбачала кримінальну відповідальність за «образу підлеглим військовослужбовцем свого начальника під час виконання останнім службових обов'язків, якщо образа нанесена насильницькими діями (ч. 1); якщо ж образа була нанесена тільки на словах або ненасильницькими діями (ч. 2)» [4, с. 490], то це був інший злочин, який відрізнявся від попереднього за ч. 1 способом його вчинення як ознакою об'єктивної сторони.

Було прийнято КК УРСР 1960 р. ст. $235 \mathrm{KK}$ («Погроза начальникові»), яка передбачала кримінальну відповідальність за пунктом а) - погрозу вбивством, заподіянням тілесних ушкоджень або нанесенням побоїв начальникові у зв'язку 3 виконанням ним обов'язків на військовій службі», 
а п. а) ст. 236 («Насильницькі дії щодо начальника») встановив кримінальну відповідальність за «а) Нанесення тілесних ушкоджень або побоїв начальникові у зв'язку з виконанням ним обов'язків на військовій службі». Крім того, пункт в) ст. 237 КK («Образа підлеглим начальника й начальником підлеглого») передбачав покарання у вигляді позбавлення волі на строк від шести місяців до п'яти років за образу насильницькими діями, нанесеними за умов, зазначених у пункті «а» цієї ст., тобто за «образу на словах або насильницькою дією підлеглим начальника чи молодшим старшого, а так само начальником підлеглого чи старшим молодшого під час виконання хоча б одним із них обов'язків на військовій службі» [5]. Надалі у КК України від 5 квітня 2001 р., зазначені злочини «Погроза начальникові» й «Насильницькі дії щодо начальника» були об'єднані у ст. 405 KK [6]. У ч. 1 цієї ст. законодавцем була додатково криміналізована погроза начальникові «знищенням чи пошкодженням його майна», а в ч. 2 «насильство щодо начальника» - «вчинення інших насильницьких дій». Дії за ст. 237 КК УРСР 1960 р. («Образа підлеглим начальника або начальником підлеглого») на словах або ненасильницькими діями були декриміналізовані ще раніше на підставі Указу Президії Верховної Ради УРСР від 29 лютого 1984 р. [7].

Суспільна небезпечність обох злочинів «погроза або насильство щодо начальника» посягає на його можливість у будь-яких умовах виконувати свої обов'язки й рішуче керувати діями підлеглих в інтересах військового правопорядку. Зі свого боку, насильницькі дії щодо начальника, до якого підлеглий, згідно зі статутами Збройних Сил України, повинен виявляти повагу і якого повинен захищати в бою, є надзвичайно грубою формою порушення військової дисципліни й утруднює виконання начальником / командиром своїх обов'язків із військової служби та спричиняє шкоду їньому здоров’ю.
Прикладом такої ситуації може слугувати засудження прапорщика Особа_1, який 19.08.2015р., бувши призначеним до складу прикордонного наряду як старшого, в районі населеного пункту на території Бердянського району Запорізької області разом із підлеглими вжили спиртні напої. Факт порушення порядку несення прикордонної служби прапорщиком Особа_1 і його двома підлеглими був виявлений трьома офіцерами Бердянського прикордонного загону, які, відповідно до своїх функціональних обов'язків, здійснювали перевірку порядку несення прикордонним нарядом служби. «Діючи умисно та усвідомлюючи суспільно-небезпечний характер своїх діянь, передбачаючи настання суспільно-небезпечних наслідків та бажаючи їх настання, прапорщик Особа_1 висловив майору ОСОБА_2, майору ОСОБА_3 та старшому лейтенанту ОСОБА_4, які для ОСОБА_1 являються начальниками за військовим званням, погрозу вбивством. Одразу після висловлених погроз убивством ОСОБА_1 перевів запобіжник автомату HOMEP_1, який був у нього, в положення автоматичного вогню, зарядив його шляхом досилання патрону в патронник та, направивши ствол автомату в бік майора ОСОБА_2, майора ОСОБА_3 та старшого лейтенанта ОСОБА_4, знову висловив їм погрозу вбивством із застосуванням зброї» [8]. Лише завдяки своєчасним діям інших військовослужбовців у прапорщика Особа_1 автомат, заряджений патроном калібру 5,45 мм та готовий для стрільби, був відібраний.

За вчинення військового злочину, передбаченого ч. 4 ст. 405 KK України, який за мірою покарання є тяжким злочином, прапорщика Особа_1 суд визнав винним у вчиненні зазначеного злочину і призначив йому покарання на підставі ч. 1 ст. 69 KK України у вигляді тримання в дисциплінарному батальйоні військовослужбовців на строк один рік.

Не піддаючи сумніву вірність кваліфікації вчиненого злочину, водночас уважаємо, що суд ступінь суспільної 
небезпеки, яка трапилась, недооцінив. Підтвердженням зазначеного може бути той факт, що погроза вбивством 3-м начальникам у зв'язку з виконанням ними обов'язків із військової служби, пов'язаної 3 охороною державного кордону України, трапилась у період діï в державі особливого періоду, крім воєнного стану, а також особою, яка в момент учинення злочину перебувала у стані алкогольного сп'яніння.

Аргументом на підтримку вищезазначеного може бути й думка О.О. Пащенка, який зазначає, що «загальновизнаним у кримінально-правовій доктрині $є$ розуміння суспільної небезпечності як соціальної, якісної ознаки, яка віддзеркалює матеріальну сутність злочину й полягає в тому, що діяння заподіює чи створює загрозу заподіяння істотної шкоди фізичній чи юридичній особі, суспільству або державі. Вона має значення не лише для визнання діяння злочином, але і для караності останнього. Тобто для охоронних кримінально-правових норм суспільна небезпечність діянь, відповідальність за які ними передбачена, має братись до уваги також під час аналізу санкцій, а не лише диспозицій» [2, с. 173].

Суспільна небезпечність конкретної правової норми Особливої частини КK співвідноситься із соціальною обумовленістю кримінально-правових норм як частина й ціле. Тому говорячи про суспільну небезпечність військових злочинів загалом, варто підтримати позицію С.О. Харитонова в тому, що соціальна обумовленість передбачити кримінальну відповідальність за військові злочини визначається різними факторами (підставами), серед яких основними, на його думку, є такі:

1 ) «підвищений ступінь суспільної небезпечності злочинів проти встановленого порядку несення військової служби, що створює загрозу боєздатності військових частин і підрозділів;

2) поширеність цих злочинів у військовому середовищі;

3) особливий характер військової служби, котра спрямована на гарантування воєнної безпеки держави від зовнішніх і внутрішніх загроз із використанням зброї, що пов'язана з небезпекою для життя і яка має пріоритет перед іншими видами державної служби та іншою діяльністю;

4) особливий правовий статус військовослужбовців, пов'язаний зі специфікою завдань, які вони виконують;

5) виокремлення у кримінальному законодавстві питання захисту інтересів військової служби в самостійний розділ» $[9$, с. 57$]$.

Окремі із зазначених факторів суспільної небезпечності військових злочинів конкретизує M.I. Карпенко, який щодо цього зазначає, що «змістом основних чинників соціально-правової обумовленості заборони військових злочинів, передбачених ст.ст. 402-435 KK, є:

1) соціально-кримінологічний полягає в небезпеці завдання шкоди суспільним відносинам, які становлять зміст військового правопорядку як родового об'єкта кримінально-правової охорони;

2) нормативно-правовий - свідчить, що ця заборона повинна відповідати нормам Конституції України; внутрішній логічній несуперечливості заборони, передбаченої ст.ст. 402-435 KK, іншим нормативно-правовим актам, котрі стосуються військової сфери;

3) культурно-історичний - свідчить, що заборона розглядається як продукт історії й культури та відповідає розвитку українського суспільства;

4) етичний - зазначає, що заборона відповідає моральним нормам;

5) міжнародно-правовий - ця заборона грунтується на стандартах норм із прав військовослужбовців, інших осіб та їх безпеки під час несення та проходження військової служби»[10, с. 24].

Так, за період дії чинного КK Украіни протягом 2001-2019 рр. за вчинення військових злочинів за даними Міністерства юстиції України, а потім Державної судової адміністрації Украіни було засуджено 19022 військовослужбовці [11, с. 421-425].

У свої сукупності наведені фактори достатнім чином зумовлюють 
необхідність установлення, збереження та подальшого вдосконалення кримінальної відповідальності за військові злочини. До того ж ураховуючи їх зростаючу суспільну небезпечність не лише для військового правопорядку, а і для воєнної безпеки України, M.I. Карпенко запропонував «передбачити розділ XIX Особливої частини КK в новій редакції, змінивши йому не лише назву на («Кримінальні правопорушення проти воєнної безпеки України»), але і зміст, розмістивши на початку оновленої Особливої частини КK після розділів «Кримінальні правопорушення проти миру, безпеки людства та міжнародного правопорядку» і «Кримінальні правопорушення проти основ національної безпеки України. Зокрема, глава 1 цього розділу повинна передбачати кримінальну відповідальність за «Кримінальні правопорушення проти порядку комплектування сектору безпеки й оборони України». До цієї глави мають бути додані правопорушення за:

1) ухилення від призову на військову службу в мирний час;

2) ухилення від призову на військову службу за мобілізацією;

3) ухилення від проходження служби цивільного захисту в особливий період чи в разі проведення цільової мобілізації;

4) ухилення від військового обліку або спеціальних зборів, вилучивши ці злочини з розділу XIV Особливої частини КК. Глава 2 «військові кримінальні правопорушення» повинна передбачати відповідальність за злочини, що нині передбачені ст.ст. 402-421, 425-432 KK, а також за кримінальні проступки. Глава 3 «Кримінальні правопорушення проти порядку забезпечення режиму особливого періоду» має передбачати кримінальну відповідальність за: ухилення від направлення на роботи на посадах цивільного персоналу, передбачених штатами воєнного часу; невиконання воєнно-транспортного обов'язку в період мобілізації й у воєнний час; невиконання повинностей в особливий період та у воєн- ний час; невиконання організаціями обов'язків в особливий період і у воєнний час, якими спричинено істотну шкоду або тяжкі наслідки» [10, с. 30].

Суспільна небезпечність злочину «погроза або насильство щодо начальника» за ст. 405 KK України, як і загалом військові злочини, передбачені нині ст.ст. 402-422, 425-435 KK, характеризуються високим рівнем небезпеки як для військового середовища, так і для держави загалом, що має бути визначальним для посилення профілактики та боротьби кримінально-правовими засобами 3 військовою злочинністю. Водночас питання суспільної небезпечності не втрачають своєї актуальності i спонукають на необхідність пошуку подальших шляхів удосконалення як їх змісту, так і практики застосування.

У статті аналізуються питання суспільної небезпечності військового злочину, передбаченого cm. $405 \mathrm{Kpu-}$ мінального кодексу Украӥни, який передбачає кримінальну відповідальність за погрозу або насильство щодо начальника. Звертається увага на те, що й покарання за його вчинення має бути адекватне, відповідно до тієї шкоди, яка спричиняється військовому правопорядку в разі його вчинення. Зазначені фактори мають бути визначальними для посилення боротьби кримінально-правовими засобами з військовою злочинністю, яка досягла критичних масштабів протягом 2015-2019 рр. $i$ є загрозою для воєнної безпеки нашої держави.

Стаття розкриває питання військових злочинів, де законодавство неодноразово змінювалось, удосконалювалось, але злочини продовжують становити для військового правопорядку суспільну небезпеку, тому й залишаються у Кримінальному кодексі України у «статусі» військових злочинів (кримінальних правопорушень).

У статті зазначається також, що суспільна небезпечність злочину за ст. 405 КК України визначається тим, щз погроза порушує встановлений порядок тим, що може 
злякати начальника/командира, негативно вплинути на їхню службову діяльність, заподіяти шкоду життю, недоторканності командира й начальника, їх здоров'ю, особистій психічній $i$ психологічній недоторканності. Злочин унеможливлюе виконання ними статутних вимог щодо військової дисципліни та загалом заважає збереженню загальної поваги, взаємодії в досягненні спільних иілей, зокрема захисту громадян України від зовнішнього ворога.

Крім того, загальною рисою щодо суспільної небезпеки иієї групи злочинів є заподіяння суттєвої шкоди суспільним відносинам, котрі забезпечують належну злагодженість, впорядкованість у військових частинах, боєготовність, боєздатність військових формувань на підставі врегульованого нормативними актами порядку підлеглості та військовій честі.

Цей злочин посягае на можливість начальника/командира керувати діями підлеглих в інтересах військової дисципліни й порядку. Тим більше насильнищькі дї щодо командира/начальника, яким підлеглий, відповідно до вимог військових статутів, зобов'язаний надавати повагу та яких повинен захищати в бою, $\epsilon$ грубою формою порушення військової дисциилліни, щь ускладнюе виконання командиром/начальником своїх обов'язків із військової служби й завдає щкоди його здоровюю. Такі дї щодо командира/начальника можуть бути помстою за їхню справедливу вимогливість, тому кримінальний закон відносить розглянуте діяння до тяжких злочинів.

Крім того, автор статmі зверmaє увагу на необхідність у проиесі здійснення судочинства виносити більи суворі вироки за скоєний злочин за сm. 405 КК України, погроза або насильство щодо начальника, задля забезпечення загального суспільного захисту.

Ключові слова: суспільна небезпечність, військовий злочин, погроза або насильство щодо начальника, воєнна безпека України, порядок несення або проходження військової служби, кримінальне правопорушення, захист.

Fierieva $\mathbf{N}$. The concept and social danger of crime "threat or violence against a commander"

The article analyzes the issues of public danger of war crime under Art. 405 of the Criminal code of Ukraine which provides criminal liability for threats or violence against a commander. Attention is drawn to the fact that the punishment for committing a crime shall be relevant in accordance with the damage caused to the military law and order in case of committing a crime. These factors shall be significant for strengthening the fight against war crimes by criminal law, which reached the critical extend during 2015-2019 and is a threat to the military security of our state.

The article reveals the issue of war crimes where the legislation has been repeatedly changed and improved, but crimes continue to pose public danger to the military law and order, and therefore remain in the Criminal Code of Ukraine in the "status" of war crimes (criminal offenses).

The article also states that public danger of a crime under Article 405 of the Criminal Code of Ukraine is determined by the fact that the threat that violates the established order can frighten the chief/commander, negatively affect their official activities, harm the life, immunity of the commander and chief, their health, personal mental and psychological integrity.

The crime makes it impossible for them to comply with the statutory requirements for military discipline and, in general, hinders the preservation of general respect and cooperation in achieving common goals, in particular protection of the citizens of Ukraine from the external enemy.

In addition, a common feature of the social danger of this group of crimes 
is the infliction of significant damage to public relations, ensuring proper coherence, orderliness in military units, combat readiness, combat capability of military formations on the basis of regulations and subordination and military honor.

This crime encroaches on the ability of the chief / commander to control the actions of subordinates in the interests of military discipline and order. Moreover, violent actions against a commander/chief that he is subject to in accordance with the requirements of military statutes, and has to protect in battle, are a gross form of violation of military discipline, which complicates the commander/chief's duties in military service and harms his health. Such actions against the commander / chief may be revenge for their justified demands, so the criminal law classifies the act in question as a felony.

In addition, the author of the article draws attention to the need in court proceedings, to impose harsher sentences for a crime under Article 405 of the Criminal Code of Ukraine, threats or violence against the chief, to ensure general public protection.

Key words: public danger, war crime, threat or violence against the chief, military security of Ukraine, the order of military service, criminal offense, protection.

\section{Література}

1. Военный энииклопедический словарь / пред. гл. ред. комиссии. Н.В. Огарков. Москва : Воениздат, 1983. 863 с. с ил., 30 л. uл.
2. Пащенко О.О. Соціальна обумовленість закону про кримінальну відповідальність : монографія. Харків : Юрайт, 2018. $446 \mathrm{c}$.

3. Сташис B.B., Бажанов М.I. Шляхи оновлення кримінального законодавства України. Вісн. Акад. прав. наук України. 1993. Bun. 1. C. 119

4. Уголовный Кодекс Советских республик / текст и постатейный комментарий под редакцией С. Канарского. 2-е издание. Государственное издательство Украины. 1925. $506 \mathrm{c}$.

5. Збірник законів Української РСР $і$ Указів Президї Верховної Ради Української РСР 1938-1973 рр. У двох томах. Т. 2. Київ : Видавництво політичної літератури України, 1974. С. 403-404.

6. Кримінальний кодекс України : Закон України від 5 квітня 2001 р. № 2341-III. Відомості Верховної Ради України (ВВР). 2001. № 25-26. Cm. 131 .

7. Відомості Верховної Ради. 1984. № 11. Cm. 203.

8. Вирок Бердянського міськрайонного суду Запорізької області від 24 вересня 2015 p. Справа № 310/8461/15-к. Провадження № 1-кn/310/502/15. URL: http: / / www.reyestr.court.gov.ua / Review / 51138969 (дата звернення: 12.05.2020).

9. Харитонов С.О. Кримінальна відповідальність за військові злочини за кримінальним правом України : монографія. Харків : Право, 2018. 328 с.

10. Карпенко M.I. Теоретико-методологічне дослідження злочинів проти встановленого порядку несення військової служби за Кримінальним кодексом України : автореф. дис. ... докт. юрид. наук : 12.00 .08 ; Університет державної фіскальної служби України. Iрпінь. 2020. 40 c.

11. Карпенко М.I. Військові злочини: питання теорії, законодавства $і$ практики : монографія. Київ : 3 ВО «Начіональна академія управління», 2019. 458 с. 